\title{
Determination of galectin-3, hepsin (Tmprss 1) and thyroid transcription factor-1 levels in thyroid cancer patients: A prospective case-control study
}

\author{
Tiroit kanserli hastalarda galektin-3, hepsin (Tmprss1) ve tiroit transkripsiyon faktör-1 \\ seviyelerinin belirlenmesi: Bir prospektif vaka-kontrol çalışması
}

Ufuk Memiş ${ }^{1}$, Erdem Karadeniz ${ }^{1}$, Müfide Nuran Akçay ${ }^{1}$, Nurinnisa Öztürk ${ }^{2}$

\begin{abstract}
Aim: This study aimed to the efficiacy of usage galectin-3, hepsin, and thyroid transcription factor-1 (TTF-1) levels as markers for the differentiation between patients with malignant and benign thyroid nodules.

Methods: The study was done prospectively between January 2018 and April 2018 in our clinic, in patients who were diagnosed with thyroid nodules and scheduled for surgery. Galectin-3, hepsin, and TTF-1 levels were measured in the preoperative serum of the benign and malignant groups. The measured levels were evaluated statistically to determine whether there was any significant difference between the malignant and benign groups. Results: When the levels of galectin-3, hepsin, and TTF-1 in the malignant and benign groups were compared, there was a statistically significant difference in TTF-1 levels $(\mathrm{p}=0.038)$. However, no significant difference was found in hepsin and galectin-3. When the macropapillary and micropapillary types were compared within the malignant patient group, there was a significant difference between the galectin-3 levels $(p=0.009)$, but no difference was found between hepsin and TTF-1.

Conclusions: It was seen that the decrease of galectin-3 levels in thyroid papillary carcinoma could be effective in the transformation from microcarcinoma to macrocarcinoma, and TTF-1 could be an important marker for the differentiation between benign and malignant thyroid nodules.
\end{abstract}

Keywords: Galectin-3, hepsin, TTF-1, thyroid malignancy, cancer.

Öz

Amaç: Çalışmada; galektin-3, hepsin ve tiroit transkripsiyon faktör-1 (TTF-1)'in kan değerlerinin tiroi nodüllerinde malign ve benign ayrımındaki tanısal değerini araştırmayı amaçladık.

Yöntemler: Çalışma kliniğimizde Ocak 2018 ile Nisan 2018 tarihleri arasında tiroit nodülü nedeniyle operasyon planlanan hastalarda prospektif olarak yürütüldü. Benign ve malign grupların ameliyat öncesi elde edilen serumlarında galektin-3, hepsin ve TTF-1 seviyeleri açısından farklılık olup olmadığı istatistiksel olarak araştırıldı.

Bulgular: Malign ve benign grupta ölçülen galektin-3, hepsin ve TTF-1 seviyeleri karşılaştırıldığında; TTF-1 seviyelerinde istatistiksel olarak anlamlı fark bulunurken $(\mathrm{p}=0,038)$, hepsin ve galektin-3'te anlaml fark tespit edilmedi. Malign hasta grubunda makropapiller ve mikropapiller tip karşılaştırıldığında galektin-3 seviyeleri arasından anlamlı bir fark tespit edilirken $(\mathrm{p}=0,009)$, hepsin ve TTF-1 arasında fark tespit edilmedi.

Sonuç: Tiroid papiller karsinomunda galectin-3 seviyesinin düşmesinin mikro karsinomdan makro karsinoma dönüşümde etkili olabileceği, TTF-1' in tiroid nodüllerinde benign ve malign ayrımında önemli bir belirteç olabileceği görüldü.

Anahtar Kelimeler: Galektin-3, hepsin, TTF-1, tiroid malignitesi, kanser.
${ }^{1}$ Ataturk University, Faculty of Medicine, Department of General Surgery, Erzurum,

\section{Turkey.}

${ }^{2}$ Ataturk University, Faculty of Medicine,

Department of Biochemistry, Erzurum, Turkey.

UM: 0000-0003-3393-3301

EK: 0000-0001-6319-1754

MNA: 0000-0001-8470-174

NÖ: 0000-0002-7746-2700

Ethics Committee Approval: The study wass approved by the local ethical authority (15.02.2018/24).

Etik Kurul Onayı: Calıșma lokal etik komite tarafından onaylanmıştır (15.02.2018/24)

Conflict of Interest: No conflict of interest was declared by the authors.

Çıkar Çatışması: Yazarlar çıkar çatışması bildirmemişlerdir.

Financial Disclosure: The present work was supported by the Scientific Research Projects Coordination Unit of Atatürk University (Project No: TTU-2018-6644)

Finansal Destek: Yazarlar bu çalışma için Ataturk Universitesi Arastirma Fonundan finansal destek aldıklarını beyan etmișlerdir (Proje No: TTU-2018 6644)

Geliş Tarihi / Received: 22.05.2019

Kabul Tarihi / Accepted: 28.08.2019

Yayın Tarihi / Published: 01.12.2019

Sorumlu yazar / Corresponding author: Erdem Karadeniz

Adres/Address: Dept of General Surgery, Faculty of Medicine, Ataturk University, 25040, Erzurum, Turkey.

e-posta: erdem7600@hotmail.com.tr

Tel/Phone: +905053543394

Copyright $(\mathcal{C}$ ACEM 


\section{Introduction}

The incidence of thyroid cancer has increased compared to previous years. The annual incidence of thyroid malignancies in the United States increased from 4.9 in 100,000 in 1975 up to 14.3 in 2009 . Although the mortality rate in thyroid cancers varies between $8-20 \%$, it is higher than other endocrine organ tumors [1].

Thyroid nodules are very common within the community. When evaluated by neck ultrasonography (US), thyroid nodules are found in $17-67 \%$ of the adult population [2]. Although most thyroid nodules are benign, recently the incidence of thyroid cancer is increasing dramatically [3]. Malignancy rate in thyroid nodules is between 5\% and 20\% [4]. Patient history, physical examination, serum thyroid Stimulating hormone (TSH) levels, neck USG and fine-needle aspiration biopsy (FNAB) constitute the standard nodule evaluation protocol. FNAB is a safe, fast, and cost-effective diagnostic tool and accepted as the gold standard for the evaluation of thyroid nodules [2]. According to the results of the FNAB, there is a gray zone such as in the Bethesda category 3 and category 4 patient groups, where although the majority of the nodules are benign in the postoperative pathology results, the surgical option is preferred because the benign-malignant distinction of the nodule is not clear. New diagnostic markers are needed to avoid unnecessary surgery especially in patients of this intermediate category.

Galectins are proteins classified as part of the lectin group and act on the cell surface and cytoplasm. Galectin-3, takes part in the intercellular relationship, cell-to-matrix relationship, cell growth, and regulation of neoplastic transformation. There are new studies suggesting that galectin-3 is a marker of malignancy in thyroid cancers, specifically in papillary thyroid cancer [5].

Type 2 transmembrane epithelial serum proteases are a newly identified subgroup of the serine protease family consisting of 17 proteolytic enzymes. Hepsin is a subtype of the type 2 transmembrane epithelial serine proteases. In vitro studies have shown that hepsin is essential for cell growth, maintenance of normal morphology of the cell, and cell motility and development [6]. Serine proteases have been shown to play a role in tumor development and metastasis [7].

Thyroid transcription factors regulate genes that code the proteins related to thyroid hormone syntheses such as thyroglobulin, thyroid peroxidase, thyrotropin receptor, the sodium- iodide symporter, and those that affect the development of the thyroid at the embryological period [8]. Thyroid transcription factor (TTF-1) has been shown to exist in the human thyroid, lung, and brain cells and may be a diagnostic and prognostic marker in lung cancers [9].

In this study; we aimed to evaluate the diagnostic value of blood galectin-3, hepsin, and TTF-1 levels in the differentiation of malignant and benign thyroid nodules.

\section{Material and methods}

\section{Study design}

This study was carried out prospectively with patients who were scheduled for operation due to the presence of thyroid nodules between January 2018 and April 2018 at our clinic. The study was approved by the University Ethics Committee on the 15th of February 2018 (No:24). The study was conducted in accordance with the Declaration of Helsinki. The patients were interviewed and informed about the study face-to-face, informed consent was taken from the patients who accepted to participate in the study. A total of 120 volunteers, who accepted to participate in the study, were operated. The operations were performed by two surgeons experienced in head and neck surgery. Patients with a history of thyroid drugs, thyroid cancer, or thyroid surgery and radiotheraphy (RT) in the neck region were excluded from the study. After the rejection criteria were applied, 77 patients remained-30 patients were randomly selected from 31 patients who had malignant postoperative pathology, and 30 patients were randomly selected as a control group from 46 patients who had benign postoperative pathology. Malignant and benign groups were compared in terms of galectin-3, hepsin, and TFF-1 levels.

\section{Biochemical analysis}

An extra tube of blood was collected in addition to the routine from the patients who consented to participate in the study. The samples were then centrifuged and stored at $-80^{\circ} \mathrm{C}$ in the laboratory of the Biochemistry Department. From the plasma samples previously-stored at $-80^{\circ} \mathrm{C}$, serum galectin-3 (Catalogue no: 201-12-1952), hepsin (Catalogue no: 201-12-3942), and TTF-1 (Catalogue no: 201-12-5744) levels were measured by ELISA methods using a commercial ELISA kit (Sunredbio, Waltham, MA, USA) and an automatic ELISA reader (Dynex Magellan Biosciences Chantilly, USA) according to the kit insert. The detection range of galectin-3, hepsin, and TTF-1 kit were $0.2-60 \mathrm{ng} / \mathrm{mL}, 0.78-50 \mathrm{ng} / \mathrm{mL}$, and $0.05-12 \mathrm{ng} / \mathrm{mL}$, respectively.

\section{Statistical analysis}

Statistical analysis of the study was performed with the SPSS for Windows 22.00 statistical software package, and the power analysis was done using the Sample Size Power Analysis Calculation version 3.1.2 program. As a result of the power analysis, a Type I error of 0.05 and power of 0.80 , a minimal sample size of 18 patients was required to achieve a significant difference between the two means. Therefore, the experimental study with thirty patients in each group showed an effect size of 0.967. The Kolmogorov-Smirnov and Shapiro-Wilk tests were applied in order to determine whether the data showed a normal distribution and nonparametric tests were applied, as the data did not conform to a normal distribution. Data were analyzed by the Chi-square analysis and Mann--Whitney U test. Statistical significance was accepted as $\mathrm{p}<0.05$.

\section{Results}

Of the 30 patients in the study (malignant) group, seven $(23.3 \%)$ were male and $23(76.7 \%)$ were female. The mean age was $45.4 \pm 9.2$ years. Seven $(23.3 \%)$ patients had a family history of thyroid carcinoma. In preoperative US, 5 (16.7\%) patients had a unilateral nodule, and $25(83.3 \%)$ patients had bilateral nodules. Total thyroidectomy was performed in 27 (90\%) patients, and lobectomy was performed in $3(10 \%)$ patients. The histopathological type of the malignant group was papillary cancer; $18(60 \%)$ were of the micropapillary type, and $12(40 \%)$ were of the macropapillary type cancer. Of the 30 patients in the control (benign) group, $8(26.7 \%)$ were male, and $22(73.3 \%)$ were female. The mean age was $46.43 \pm 10$ years. Four $(13.3 \%)$ patients had a family history of thyroid carcinoma. Preoperatively, 12 (40\%) patients had unilateral, and $18(60 \%)$ patients had bilateral nodules. Total thyroidectomy was performed in $16(53.3 \%)$ patients, and lobectomy was performed in $14(46.7 \%)$ patients. A comparison of the characteristics of the patients in the malignant and benign patients in terms of their characteristics is given in Table 1. 
Table 1. Comparison of the characteristics of the patients in the malignant and benign groups.

\begin{tabular}{|c|c|c|c|c|}
\hline Parameter & & $\begin{array}{l}\text { Benign } \\
(\mathrm{n}=30)\end{array}$ & $\begin{array}{c}\text { Malignant } \\
(\mathrm{n}=30)\end{array}$ & $\mathrm{p}$ \\
\hline Age $^{*}$ & & $46.43 \pm 10$ & $45.40 \pm 9.2$ & 0.679 \\
\hline \multirow[t]{2}{*}{ Gender $^{\beta}$} & Male & $8(26.7)$ & $7(23.3)$ & \multirow{2}{*}{0.766} \\
\hline & Female & $22(73.3)$ & 23 (76.7) & \\
\hline \multirow{2}{*}{$\begin{array}{l}\text { History of } \\
\text { thyroid } \\
\text { cancer in } \\
\text { family }^{\beta}\end{array}$} & Present & $4(13.3)$ & $7(23.3)$ & \\
\hline & Absent & $26(86.7)$ & $23(76.7)$ & 0.317 \\
\hline \multirow[t]{3}{*}{ US nodule ${ }^{\beta}$} & Unilateral nodule & & & \\
\hline & & $12(40.0)$ & $5(16.7)$ & \\
\hline & Bilateral nodule & $18(60.0)$ & $25(83.3)$ & 0.045 \\
\hline \multirow[t]{2}{*}{ Operation $^{\beta}$} & $\begin{array}{l}\text { Total } \\
\text { thyroidectomy }\end{array}$ & $16(53.3)$ & $27(90.0)$ & \\
\hline & Lobectomy & $14(46.7)$ & $3(10.0)$ & 0.002 \\
\hline
\end{tabular}

$\beta$ : n (\%), ¥: mean \pm standard deviation

The mean of the TFF-1 levels in the malignant patient group was $6.02 \pm 3.19 \mathrm{ng} / \mathrm{ml}$, and the median was $35.17 \mathrm{ng} / \mathrm{ml}$, the mean in the benign patient group was $4.54 \pm 2.54 \mathrm{ng} / \mathrm{ml}$, and the median was $25.83 \mathrm{ng} / \mathrm{ml}$, and the difference was significant $(\mathrm{p}=0.038)($ Table 2) (Figure 1).

Table 2. Comparison of Galectin-3, hepsin (TMPRSS1) and thyroid transcription factor-1 (TTF-1) levels in patients with malignant and benign groups.

\begin{tabular}{lccc} 
Parameter & Benign $(\mathrm{n}=30)$ & $\begin{array}{c}\text { Malignant } \\
(\mathrm{n}=30)\end{array}$ & $\mathrm{p}$ \\
\hline Galektin-3 (ng/ml) $^{\mu}$ & $13.61 \pm 8.21$ & $19.10 \pm 12.99$ & \\
& $(26.53)$ & $(34.47)$ & 0.079 \\
Hepsin (TMPRSS1) $(\mathrm{ng} / \mathrm{ml})^{\mu}$ & $18.31 \pm 11.32$ & $24.66 \pm 19.93$ & \\
& $(28.67)$ & $(32.33)$ & 0.416 \\
Thyroid transcription factor-1 $^{\mu}$ & $4.54 \pm 2.54$ & $6.02 \pm 3.19$ & \\
$(\mathrm{ng} / \mathrm{ml})^{\mu}$ & $(25.83)$ & $(35.17)$ & 0.038
\end{tabular}

$\mu:$ mean \pm standard deviation (median)

The malignant patient group were grouped as macropapillary and micropapillary according to their pathologies and the galectin-3, hepsin, and TTF-1 levels of the patients were compared. The mean and the median of the galectin-3 levels was $13.55 \pm 11.04 \mathrm{ng} / \mathrm{ml}$ and $10.33 \mathrm{ng} / \mathrm{ml}$, and in the patients were $22.81 \pm 13.15 \mathrm{ng} / \mathrm{ml}$ and the median was $18.94 \mathrm{ng} / \mathrm{ml}$ in the macropapillary and micropapillary patients, respectively, and the difference was significant ( $\mathrm{p}=0.009)$ (Table 3) (Figure 2).

Table 3. Comparison of Galectin-3, Hepsin (TMPRSS1) and thyroid transcription factor-1 levels in patients with macropapillary and micropapillary thyroid cancers in malignant groups

\begin{tabular}{|c|c|c|c|}
\hline Para & $\begin{array}{l}\text { Macropapilla } \\
(\mathrm{n}=12)\end{array}$ & $\begin{array}{l}\text { Iicropapillary } \\
(\mathrm{n}=18)\end{array}$ & $p$ \\
\hline${\mathrm{Galektin}-3(\mathrm{ng} / \mathrm{ml})^{\mu}}^{\mu}$ & $\begin{array}{l}13.55 \pm 11.04 \\
(11.33)\end{array}$ & $\begin{array}{l}22.81 \pm 13.15 \\
(18.94)\end{array}$ & 0.009 \\
\hline TMPRSS1) $(\mathrm{ng} / \mathrm{ml})^{\mu}$ & $\begin{array}{l}19.76 \pm 18.25 \\
(13.17)\end{array}$ & $\begin{array}{l}27.92 \pm 20.83 \\
(17.06)\end{array}$ & 0.236 \\
\hline $\begin{array}{l}\text { Thyroid } \\
(\mathrm{ng} / \mathrm{ml})^{\mu}\end{array}$ transcription $\quad$ factor-1 & $\begin{array}{l}5.81 \pm 3.12 \\
(15.42)\end{array}$ & $\begin{array}{c}6.17 \pm 3.33 \\
(15.56)\end{array}$ & 0.966 \\
\hline
\end{tabular}

$\mu$ : mean \pm standard deviation (median)

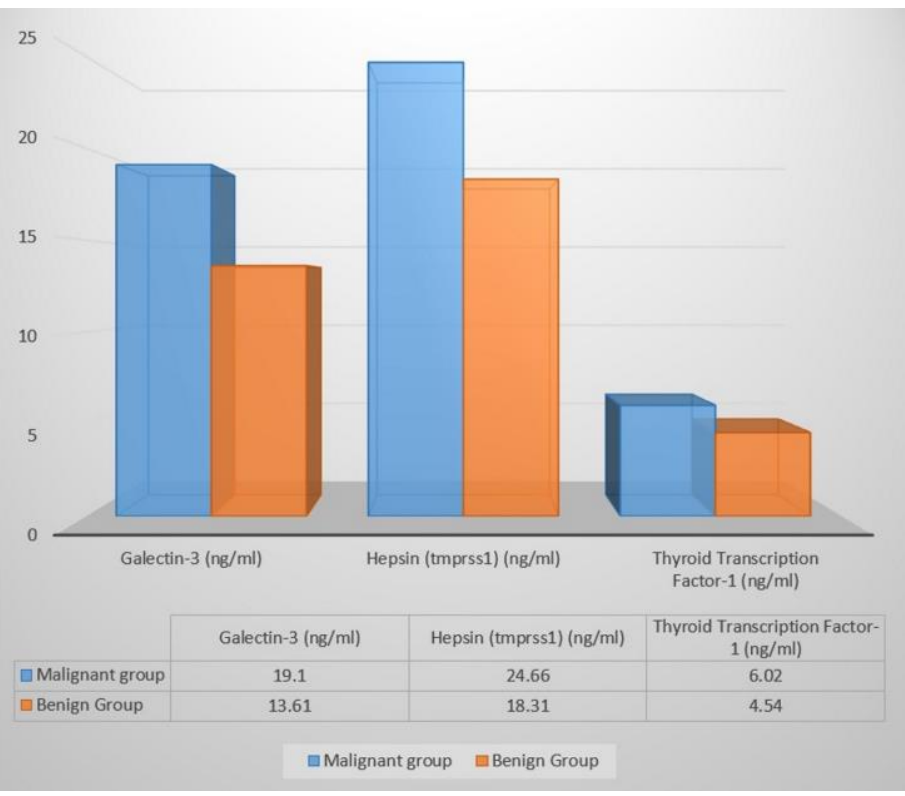

Figure 1. Galectin-3, hepsin (TMPRSS1) and thyroid transcription factor-1 (TTF-1) level in patients with malignant and benign patients.

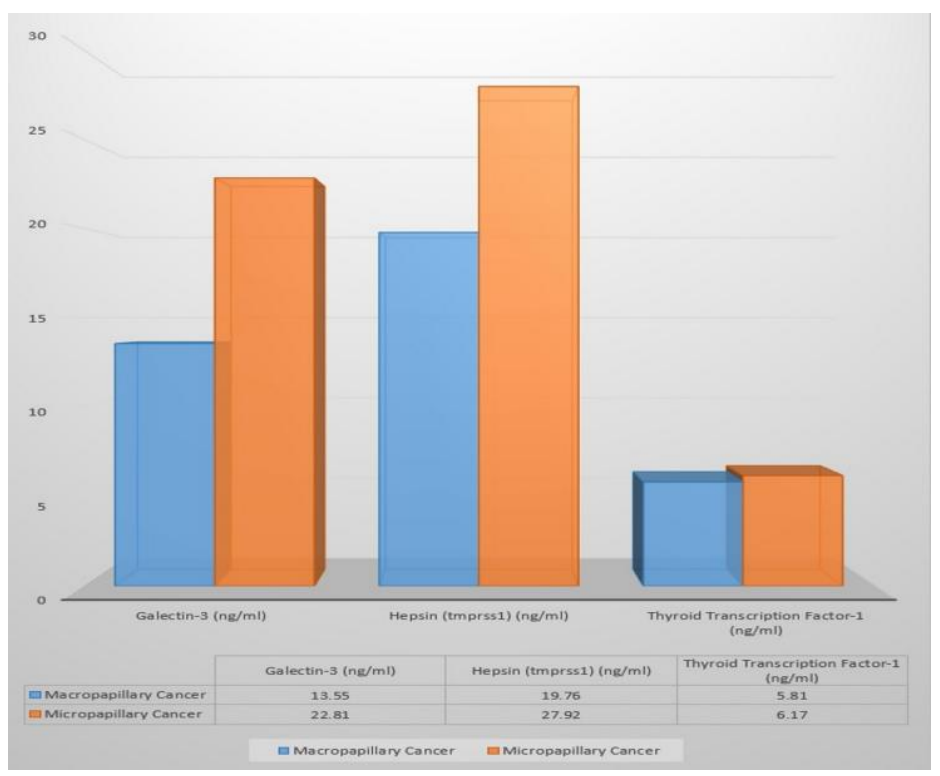

Figure 2. Galectin-3, hepsin (TMPRSS1) and thyroid transcription factor-1 levels of patients with macropapillary and micropapillary in malignant groups.

\section{Discussion}

A thyroid nodule could be described as a separate lesion that occurs in the thyroid gland and differs radiologically from the normal thyroid parenchyma. The main clinical problem in thyroid nodules is to distinguish malignancies. FNAB is golden standard for its safety, rapidity, and cost-effectivity in the evaluation of thyroid nodules. FNAB is widely used by many specialists and the false negativity rate is below $5 \%$. Combining it with US reduces the rate of false negatives and nondiagnostic cytology rates $[2,10]$. The results of the FNAB are considered as one of the most important determinants of the decision for surgery or medical treatment. According to the Bethesda classification, FNAB results separated the groups into nondiagnostic (category 1), Benign (category 2), Atypia of underdetermined Significance (AUS)/Follicular Lesion of underdetermined Significance (FLUS) (category 3), Follicular neoplasm or suspicious for a Follicular Neoplasm (category 4), 
suspicious for malignancy (category 5), and malignant (category 6). Especially in the Bethesda category 3 and category 4, patient groups are in the gray zone.

Although most of the postoperative pathology results are benign, the surgical option is applied because the benignmalignant distinction of the nodule cannot be made clear. New diagnostic markers are needed to avoid unnecessary surgery especially for patients in this intermediate category.

Galectin-3 is a beta-galactocyte binding polypeptide. It is a member of the lectin family and plays an important role in some biological processes. It plays a role in regulating cell-cell and cell-matrix interactions, adhesion, migration, and damaged cell repair. It also plays a role in inflammation and neoplastic transformation [5]. Many studies have shown that galectin-3 is a reliable diagnostic marker with high sensitivity in the preoperative diagnosis of thyroid carcinomas. In a meta-analysis of 39 studies by De Matos et al. [11], the sensitivity and specificity of galectin-3 in detecting malign thyroid lesions was $82 \%$ and $81 \%$, respectively. Galectin 3 has a high $81.9 \%$ sensitivity and $92.3 \%$ specificity in papillary thyroid carcinoma, reported to be the most effective single marker for differentiating benign from malignant tumors [12]. In our study, although the whole malignant group consisted of papillary carcinoma, serum levels of galectin-3 were higher in the malignant group consistent with other studies. But there was no statistically significant difference found between the malign and benign group that could further be explained by the low number of cases in the study. In a study by Kawachi and Ark et al. [13], papillary thyroid carcinoma patients who metastasized to the lymph nodes had more galectin-3 expression than the non-metastatic patients. However, they found that galectin-3 expression in the lymph nodes metastasized from papillary carcinoma was lower than the primary thyroid lesion. With the help of these results, the decrease in galectin-3 levels in the progression of papillary thyroid carcinoma reported could contribute to cell release and metastasis from the primary tumor [13]. In our study, there were no metastasized patients, when papillary thyroid carcinoma in the malignant group were separated into micro $(<1 \mathrm{~cm})$ and macro $(>1 \mathrm{~cm})$ papillary carcinoma according to the tumor size, galectin-3 level was higher in the micropapillary group compared to the macropapillary group and this difference was statistically significant. This result suggested that the decrease of galectin-3 level in papillary carcinoma may be effective in the microcarcinoma transformation to macrocarcinoma. Based on our study and the study by Kawachi et al. [13], in the later the stages of the disease in papillary thyroid carcinoma, the more the decrease in galectin-3 levels may be an indicator for metastasis and poor prognosis.

Hepsin is a type II transmembrane serine protease frequently overexpressed in most tissues and different tumors. Studies suggest that hepsin is required for the growth and maintenance of normal morphology, as well as for cell motility and development, initiation of blood coagulation, and proinflammatory immune response [6]. Recent studies on different malignant diseases revealed that hepsin expression increased in malignant tissues, and hepsin may have a prognostic and therapeutic value for some malignant diseases. In a study by Stephan et al. [14], they found that hepsin expression in malignant prostate tissue was higher than normal prostate tissue. In $53 \%$ of patients, it was more than 10 times higher. They also reported that high hepsin expression was associated with the degree of disease and may be a prognostic marker. Xing et al. [15] reported that the expression of hepsin in cancerous breast tissue was increased. The overexpression of Hepsin was associated with tumor stage, lymph node metastasis, and inhibition of hepsin expression could, therefore, be of the therapeutic importance. In a study by El-Rebey et al. [16], in 27 patients with endometrial cancer and 18 patients with endometrial hyperplasia, hepsin expression was higher in cancer patients and hepsin was reported to be associated with tumor grade and size. In a study by Tanimoto et al. [17], the effect of hepsin serine protease in patients with ovarian carcinoma showed that hepsin expression increased in patients with ovarian carcinoma. In a study by Zhang et al. [18] on patients with gastric carcinoma, high hepsin expression was associated with poor prognosis.

In our study, no significant difference was found between the thyroid malignant and benign patients in terms of hepsin expression. There is no record in the literature on hepsin in thyroid malignancy, so a comparison could not be made. There is a need for additional studies on thyroid malignancies for such a protein like hepsin that would also be important in the diagnosis and prognosis of many malignancies.

Tissue-specific transcription factors play a crucial role in regulating expression of tissue-specific genes. In this way, it controls the function, homeostasis, and differentiation of the tissue in which expression is made. Three different thyroid specific transcription factors are critical for thyroid function: NKX2-1 (TTF-1), FOXE1 (TTF-2), and PAX8. They regulate genes of thyroglobulin, thyroid peroxidase, thyrotropin receptor, and the sodium/iodide simporter, which synthesizes proteins critical for thyroid hormone synthesis. They are also important for thyroid development [19]. TTF-1 transcription factor plays a role in the production of surfactants in lung tissue and thyroglobulin secretion in thyroid glands. In a study by Anagnostou et al. [20] on patients with lung adenocarcinoma, increased TTF-1 expression in stage 1 adenocarcinoma patients was associated with long survival time and TTF-1 could be a prognostic marker in stage 1 adenocarcinoma patients. In a study by Zhang et al. [21] comparing endometrial cancer, endometrial proliferation, and normal endometrial tissue, TTF-1 expression in the tumor tissue was lower than the proliferation tissue and normal endometrial tissue so TTF-1 could be used in the diagnosis of early endometrial cancer. Daisuke et al. [22] reported that TTF-1 was expressed in only $5(18 \%)$ of 28 patients with anaplastic carcinoma. Fenton et al. [23] reported that the recurrence rate was higher in patients with TTF-1 expression in papillary thyroid carcinoma. In a study by Katoh et al. [8], TTF-1 expression was found to be lower in differentiated thyroid carcinomas compared to undifferentiated thyroid carcinomas and TTF-1 may provide information about the functional activity and differentiation of thyroid tumors Tan et al. reported, in a study comparing patients with thyroid papillary carcinoma, follicular carcinoma, and follicular adenoma, that there was no difference in TTF-1 expression between the three groups so that TTF-1 was not diagnostically beneficial. In a study by $\mathrm{Ai}$ et al. [25] comparing thyroid papillary carcinoma with healthy people, there was no relationship between TTF-1 and thyroid papillary carcinoma. In our study, TFF-1 level of the patients in the malignant group was higher than the patients in the benign group. In the literature, there are studies reporting that TTF-1 has no diagnostic role in thyroid carcinoma and there are studies indicating that TTF-1 is a prognostic marker in thyroid carcinoma. Although our study shows that TTF-1 may be a diagnostic marker in contrast to previous studies, it is a fact that new studies are needed in this field.

The single-center design of the study and the low number of cases were the key limitations of this work.

In conclusion, although there is a need for new prospective controlled studies in this area; it was seen that the decrease in galectin-3 levels in thyroid papillary carcinoma could be effective in the transformation from microcarcinoma to 
macrocarcinoma and TTF-1 could be an important marker in the benign-malign differentiation in thyroid nodules.

Acknowledgement: ELISA kits was provided in commercially available kits as part of the project supported by the Scientific Research Projects Coordination Unit of University (Project No: TTU-2018-6644).

\section{References}

1. Davies L, Welch HG. Current thyroid cancer trends in the United States. JAMA otolaryngology-head \& neck surgery. 2014;140:317-22.

2. Ogilvie JB, Piatigorsky EJ, Clark OH. Current status of fine needle aspiration for thyroid nodules. Adv Surg. 2006;40:223-38

3. Siegel R, Naishadham D, Jemal A. Cancer statistics, 2012. CA Cancer J Clin. 2012;62:10-29.

4. Brito JP, Yarur AJ, Prokop LJ, McIver B, Murad MH, Montori

VM. Prevalence of thyroid cancer in multinodular goiter versus single nodule: a systematic review and meta-analysis. Thyroid. 2013;23:44955 .

5. Abd-El Raouf SM, Ibrahim TR. Immunohistochemical expression of HBME-1 and galectin-3 in the differential diagnosis of follicularderived thyroid nodules. Pathol Res Pract. 2014;210:971-8.

6. Zhang C, Zhang M, Song S. Cathepsin D enhances breast cancer invasion and metastasis through promoting hepsin ubiquitin-proteasome degradation. Cancer Lett. 2018;438:105-15.

7. Netzel-Arnett S, Hooper JD, Szabo R, Madison EL, Quigley JP, Bugge $\mathrm{TH}$, et al. Membrane anchored serine proteases: a rapidly expanding group of cell surface proteolytic enzymes with potential roles in cancer. Cancer Metastasis Rev. 2003;22:237-58.

8. Tan A, Etit D, Bayol U, Altinel D, Tan S. Comparison of proliferating cell nuclear antigen, thyroid transcription factor1, Ki-67, p63, p53 and high-molecular weight cytokeratin expressions in papillary thyroid carcinoma, follicular carcinoma, and follicular adenoma. Ann Diagn Pathol. 2011;15:108-16.

9. Barletta JA, Perner S, Iafrate AJ, Yeap BY, Weir BA, Johnson LA, et al. Clinical significance of TTF-1 protein expression and TTF-1 gene amplification in lung adenocarcinoma. J Cell Mol Med. 2009;13:1977-86.

10. Danese D, Sciacchitano S, Farsetti A, Andreoli M, Pontecorvi A. Diagnostic accuracy of conventional versus sonography-guided fineneedle aspiration biopsy of thyroid nodules. Thyroid. 1998;8:15-21.

11. de Matos LL, Del Giglio AB, Matsubayashi CO, de Lima Farah M, Del Giglio A, da Silva Pinhal MA. Expression of CK-19, galectin-3 and HBME-1 in the differentiation of thyroid lesions: systematic review and diagnostic meta-analysis. Diagn Pathol. 2012;7:97.

12. Wu G, Wang J, Zhou Z, Li T, Tang F. Combined staining for immunohistochemical markers in the diagnosis of papillary thyroid carcinoma: improvement in the sensitivity or specificity? J Int Med Res. 2013;41:975-83.

13. Kawachi K, Matsushita Y, Yonezawa S, Nakano S, Shirao K, Natsugoe S, et al. Galectin-3 expression in various thyroid neoplasms and its possible role in metastasis formation. Hum Pathol. 2000;31:428 33 .

14. Stephan C, Yousef GM, Scorilas A, Jung K, Jung M, Kristiansen $\mathrm{G}$, et al. Hepsin is highly over expressed in and a new candidate for a prognostic indicator in prostate cancer. J Urol. 2004;171:187-91.

15. Xing P, Li JG, Jin F, Zhao TT, Liu Q, Dong HT, et al. Clinical and biological significance of hepsin overexpression in breast cancer. J Investig Med. 2011;59:803-10.

16. El-Rebey HS, Kandil MA, Samaka RM, Al-Sharaky DR, El Deeb K. The Role of Hepsin in Endometrial Carcinoma. Appl Immunohistochem Mol Morphol. 2017;25:624-631.

17. Tanimoto H, Yan Y, Clarke J, Korourian S, Shigemasa K, Parmley $\mathrm{TH}$, et al. Hepsin, a cell surface serine protease identified in hepatoma cells, is overexpressed in ovarian cancer. Cancer Res. 1997;57:2884-7.

18. Zhang M, Zhao J, Tang W, Wang Y, Peng P, Li L, et al. High Hepsin expression predicts poor prognosis in Gastric Cancer. Sci Rep. 2016;6:36902.

19. Kimura S. Thyroid-specific transcription factors and their roles in thyroid cancer. J Thyroid Res. 2011;2011:710213.

20. Anagnostou VK, Syrigos KN, Bepler G, Homer RJ, Rimm DL. Thyroid transcription factor 1 is an independent prognostic factor for patients with stage I lung adenocarcinoma. J Clin Oncol. 2009;27:271-8.
21. Zhang HM, Fan TT, Li W, Li XX. Expressions and significances of TTF-1 and PTEN in early endometrial cancer. Eur Rev Med Pharmacol Sci. 2017;21(3 Suppl):20-6.

22. Nonaka D, Tang $\mathrm{Y}$, Chiriboga L, Rivera M, Ghossein R. Diagnostic utility of thyroid transcription factors Pax8 and TTF-2 (FoxE1) in thyroid epithelial neoplasms. Mod Pathol. 2008;21:192-200. 23. Fenton CL, Patel A, Burch HB, Tuttle RM, Francis GL. Nuclear localization of thyroid transcription factor-1 correlates with serum thyrotropin activity and may be increased in differentiated thyroid carcinomas with aggressive clinical course. Ann Clin Lab Sci. 2001;31:245-52.

24. Katoh R, Kawaoi A, Miyagi E, Li X, Suzuki K, Nakamura Y, et al. Thyroid transcription factor-1 in normal, hyperplastic, and neoplastic follicular thyroid cells examined by immunohistochemistry and nonradioactive in situ hybridization. Mod Pathol. 2000;13:570-6.

25. Ai L, Yu Y, Liu X, Wang C, Shi J, Sun H, et al. Are the SNPs of NKX2-1 associated with papillary thyroid carcinoma in the Han population of Northern China? Front Med. 2014;8:113-7. 